\title{
Amniotic Fluid Concentrations of Renin and Aldosterone during Development in the Fetal Sheep
}

\author{
SHARON R. SIEGEL, ${ }^{(23)}$ \\ Department of Pediatrics, UCLA Hospital and Clinics, Los Angeles, California, USA
}

\begin{abstract}
Summary
Simultaneous plasma renin activity and aldosterone levels were measured in the chronically catheterized fetal lamb and pregnant ewe between 100 days gestation and term (140 to 150 days). Amniotic fluid renin levels were not statistically different after the addition of sheep renin substrate $[0.76 \pm 0.18 \mathrm{ng} / \mathrm{ml} / \mathrm{hr}$ (mean and S.E.) under 120 days and $1.33 \pm 0.29$ after 125 days|. Amniotic fluid renin levels were unmeasurable without the addition of renin substrate. Basal plasma renin activity levels increased from 4.27 $\pm 0.66 \mathrm{ng} / \mathrm{ml} / \mathrm{hr}(P<0.01)$ (mean and S.E.) between 95 to 120 days of gestation in the fetal lamb to $10.14 \pm 1.46$ between 125 to 150 days; these levels were greater than the amniotic fluid levels $(P<0.001)$. Basal plasma renin activity levels in the pregnant ewe increased from $2.61 \pm 0.40 \mathrm{ng} / \mathrm{ml} / \mathrm{hr}$ under 120 days of gestation to $7.13 \pm 1.41(P<0.01)$ after 125 days; these levels were greater than the simultaneous amniotic fluid levels $(P<0.001)$.

The basal amniotic fluid, fetal, and maternal aldosterone levels of 5.0 $\pm 0.53,3.45 \pm 0.53$, and $5.83 \pm 0.76 \mathrm{ng} / \mathrm{dl}$ (mean and S.E.) increased to $8.97 \pm 0.86,6.67 \pm 1.21$, and $12.28 \pm 2.87 \mathrm{ng} / \mathrm{dl}$, respectively, $(P<0.05)$. Neither the fetal nor the maternal levels were statistically different from the amniotic fluid aldosterone levels during development.

These data suggest that active renin and renin substrate pass poorly into the amniotic fluid; however, aldosterone from both the fetus and mother pass easily and contribute to the level of this steroid in amniotic fluid.
\end{abstract}

\section{Speculation}

Amniotic fluid renin activity is unmeasurable without the addition of renin substrate for generation of angiotensin I; aldosterone levels are similar to and probably contributed by the mother and fetus. It is unlikely that the amniotic renin-angiotensin-aldosterone system has a local physiologic function.

Although basal plasma aldosterone concentrations in the fetal lamb are lower than those in the pregnant ewe, both increase similarly throughout gestation (11). Pasqualini et al. (10), Bayard et al. (2), and Siegel et al. (13), have documented the placental transfer of aldosterone in the guinea pig, human, and sheep, respectively. In the chronically catheterized sheep preparation, fetal adrenal aldosterone secretion cannot be stimulated by ACTH $(21), \mathrm{K}^{+}(20)$, or furosemide (11); and a high pressor dose of angiotensin II causes only a small increase in aldosterone levels (12). This suggests that the fetus is probably not independently capable of stimulating adrenal aldosterone secretion under physiologic conditions and aldosterone concentrations are partly maintained by the mother.

Plasma renin activity (PRA) levels are higher in the fetal lamb (11) than in the pregnant ewe, and the fetus is independently capable of producing renin in response to stimulation by furosemide (11), by blood volume reduction (18), and by aortic constric- tion (18). Most of the renin in human amniotic fluid is inactive (9). It is unlikely that renin (19) or angiotensin II (3) cross the placenta.

The purpose of this study was: (1) to determine whether or not active renin and aldosterone are present in the amniotic fluid during development in the sheep, and (2) to compare amniotic levels with those of the fetus and pregnant ewe.

\section{MATERIALS AND METHODS}

Chronically catheterized fetal lamb preparations between 100 days gestation and term (140 to 150 days) were studied. Pregnant ewes were obtained from a local source and maintained in the vivarium before surgery. Rompun $(0.1$ to $0.2 \mathrm{ml})$, a tranquilizer, was administered to the ewe before uterotomy and fetal catheterization; epidural anesthesia ( $5 \mathrm{ml}$ of $2 \%$ xylocaine) was used for the surgical procedure. The uterus was exposed through a small midline abdominal incision and the head delivered through a small hysterotomy. Carotid arterial, jugular venous, and amniotic polyvinyl catheters were placed. The fetus was returned to the uterine cavity and the uterine incision closed. The catheters were brought out through skin tunnels in the lateral abdominal wall and secured in a pouch attached to the back of the ewe. The animals were maintained on ampicillin for 5 days postoperatively and then studied.

Plasma samples from 10 fetal lambs and pregnant ewes, and amniotic fluid samples were simultaneously obtained for renin and aldosterone during the 3 rd trimester (100 to 150 days gestation) in the sheep.

For measurement of PRA, the blood samples were collected in KEDTA $(150 \mu \mathrm{g} / \mathrm{ml})$ whole blood at room temperature. To 1.0 $\mathrm{ml}$ of plasma $10 \mu \mathrm{l}$ of $6.6 \mathrm{gm} \% 8-\mathrm{OH}$ quinoline, $10 \mu \mathrm{lof} 10 \mathrm{~g} / 100$ $\mathrm{ml} \beta$ mercaptoethanol and $10 \mu \mathrm{l}$ of $3 \mathrm{~g} / 100 \mathrm{ml} O$-phenanthroline were added to inhibit converting enzyme and angiotensinase. Twenty-five $\mu \mathrm{l}$ of $4.0 \mathrm{M}$ Tris-phosphate-Tris maleate buffer $\mathrm{pH}$ 6.2 was added to reach a $\mathrm{pH}$ of 6.5 for maximal generation of angiotensin $I$ in sheep blood. The blood was divided into two equal aliquots; one aliquot for a blank (frozen) and the other aliquot for generation of angiotensin I at $37^{\circ} \mathrm{C}$ for $1 \mathrm{hr}$. PRA was measured by radioimmunoassay (7). Aldosterone, after column chromatography, was measured by radioimmunoassay (8). The coefficient of intraassay variation was $8 \%$ and interassay variation $10 \%$.

Statistics were measured by Student's $t$ test.

\section{RESULTS}

Figure I shows the amniotic fluid and fetal and maternal plasma renin levels. Amniotic fluid renin levels after the addition of sheep renin substrate $(15)$ were $0.76 \pm 0.18 \mathrm{ng} / \mathrm{ml} / \mathrm{hr}$ (mean and S.E.) under 120 days, and $1.33 \pm 0.29$ after 125 days (not statistically different). Plasma renin levels were unmeasurable without the addition of renin substrate. Basal PRA levels increased from 4.27 


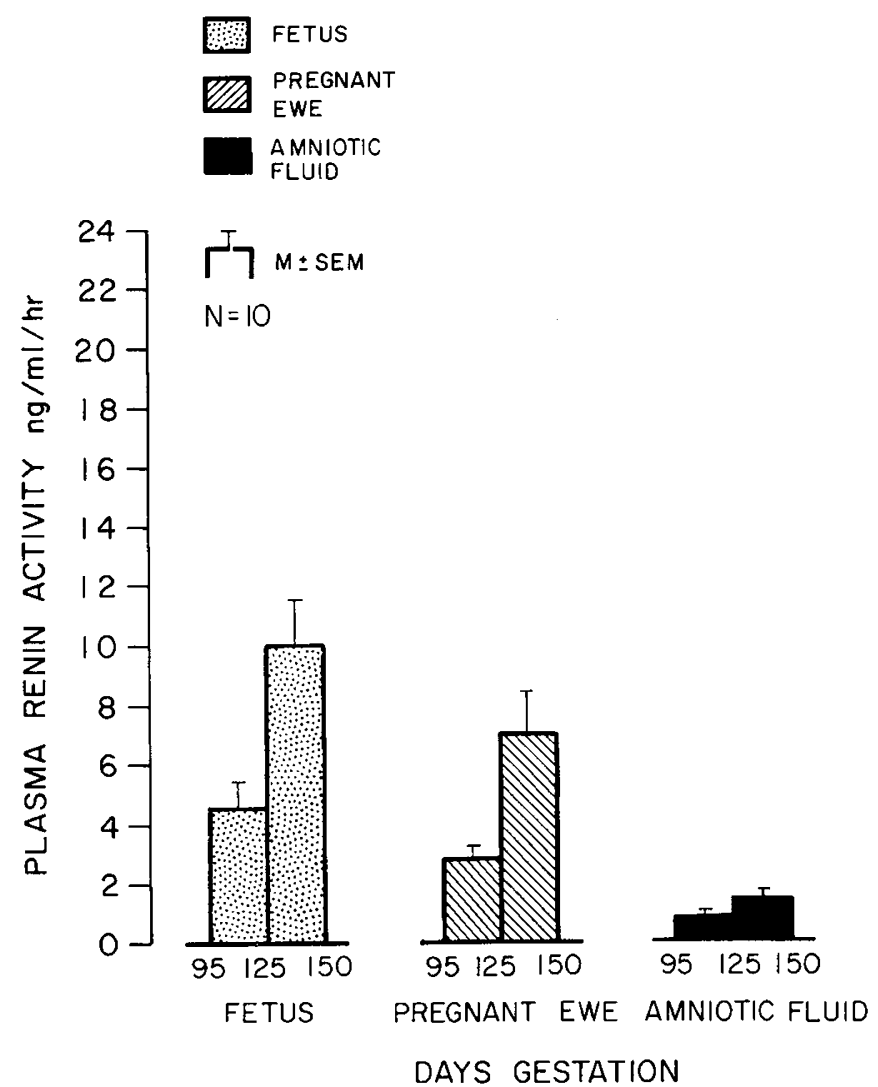

Fig. 1. Basal renin concentrations during development in the amniotic fluid, fetal lamb, and pregnant ewe.

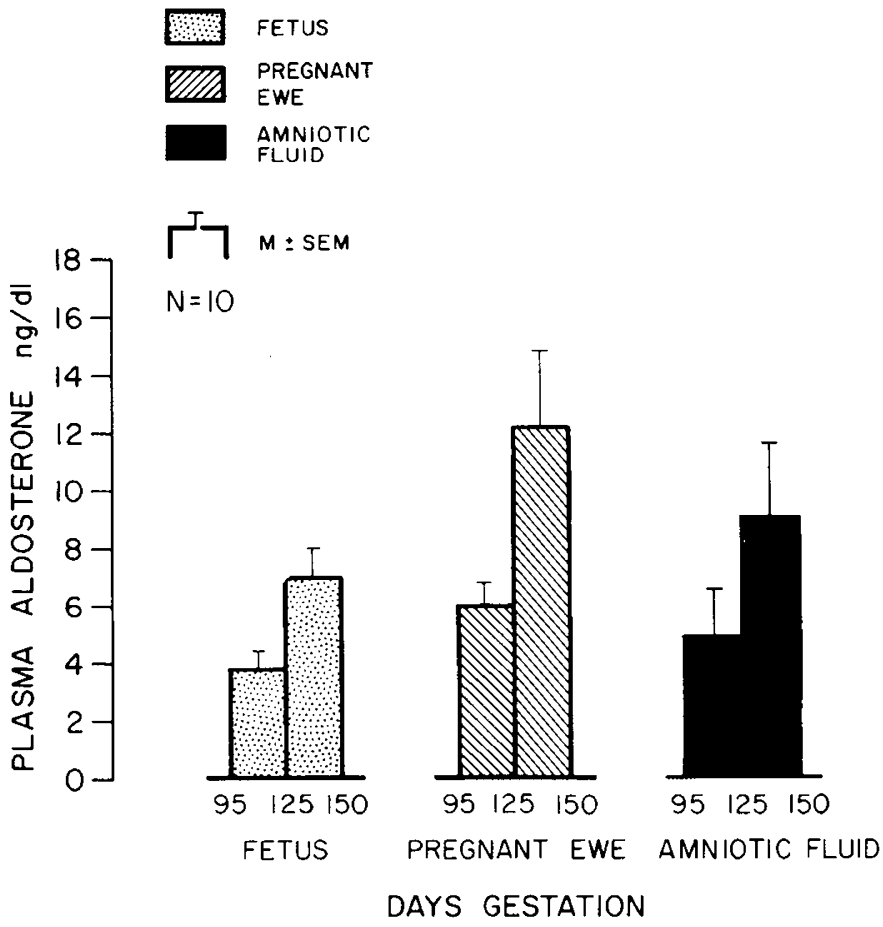

Fig. 2. Basal aldosterone levels during development in the amniotic fluid, fetal lamb, and pregnant ewe.

$\pm 0.66 \mathrm{ng} / \mathrm{ml} / \mathrm{hr}(P<0.01)$ (mean and S.E.) between 95 to 120 days of gestation in the fetal lamb to $10.14 \pm 1.46$ between 125 to 150 days. These levels were greater than the amniotic fluid levels $(P<0.001)$. Basal PRA levels in the pregnant ewe increased from
$2.61 \pm 0.40 \mathrm{ng} / \mathrm{ml} / \mathrm{hr}$ under 120 days of gestation to $7.13 \pm 1.41$ $(P<0.01)$ after 125 days. These levels were greater than the simultaneous amniotic fluid levels $(P<0.001)$.

Figure 2 shows the amniotic fluid and fetal and maternal aldosterone levels. The basal amniotic, fetal, and maternal aldosterone levels of $5.0 \pm 0.53,3.45 \pm 0.53$, and $5.83 \pm 0.76 \mathrm{ng} / \mathrm{dl}$ (mean and S.E.) increased to $8.97 \pm 0.86,6.67 \pm 1.21$, and 12.28 $\pm 2.87 \mathrm{ng} / \mathrm{dl}$, respectively $(P<0.05)$. However, neither the fetal nor the maternal levels were statistically different from the amniotic fluid aldosterone levels during development.

\section{DISCUSSION}

The amniotic fluid levels of renin and aldosterone were measured during development in the sheep to determine its relationship to the fetal and maternal plasma levels. Endogenous renin activity was unmeasurable and required the addition of renin substrate to generate angiotensin from the low amniotic fluid renin levels shown in Figure 1. The levels were statistically similar under 120 and over 125 days gestation. The fetal and maternal endogenous PRA levels increased after 125 days $(P<0.01)$, and were greater than the simultaneous amniotic fluid levels, $(P<$ 0.001 ). Skinner et al. (14) showed that endogenous renin activity, $0.8 \mathrm{ng} / \mathrm{ml} / \mathrm{hr}$, was lower in the human liquor amnii than in the maternal plasma.

It was shown by Bangham (1) that ${ }^{131}$ I-labeled serum proteins administered to pregnant rhesus monkeys rapidly appeared in the amniotic fluid. This finding raises the possibility of a similar transfer of active renin from human maternal plasma or fetal plasma to liquor. Another possibility is that the active renin in amniotic fluid originates at least partly from the cells of the placenta or decidua. Studies based on the extraction of fetal membranes and placental tissue (16) showed that human chorion contained the highest concentrations of renin outside of the kidney. However, the methodology used to measure renin involved acid activation (16), and most of the renin in amniotic fluid requires acid activation (9). Other studies have shown that approximately half the renin synthesized from chorion is acid activated and half is biologically active (4). Cultures of placental tissue have not proven a placental source of renin, and the cellular site of synthesis in the chorion remains uncertain. There appears to be evidence in nephrectomized animals that renin can be released into the systemic circulation (6), particularly after the reduction of uterine blood flow. However, it is not clear whether the myometrium, placenta, or fetus provide the major contributory source of renin under these circumstances.

Renin substrate (angiotensinogen) is a protein that is synthesized by the liver and hydrolyzed by renin to produce angiotensin I (17). Since renin substrate concentration limits the rate of renin reaction in human plasma $(5,15)$, it seems likely that entry of the large protein substrate into liquor is the rate-limiting step in local generation of angiotensin I (PRA).

Amniotic, fetal, and maternal aldosterone concentrations increased after 125 days gestation $(P<0.05)$. Neither the fetal nor the maternal aldosterone concentrations were statistically different than the simultaneous amniotic concentrations. Siegel et al. (13) has shown that aldosterone can cross the sheep placenta and passes slowly from fetus into amniotic fluid. In the chronically catheterized sheep preparation, fetal adrenal aldosterone secretion cannot be stimulated by ACTH $(21), \mathrm{K}^{+}(20)$, or furosemide (11); and a high pressor dose of angiotensin II causes only a small increase in aldosterone levels (12). Aldosterone concentrations are partly maintained by maternal levels prior to term $(10,11,22)$. Therefore, amniotic aldosterone concentrations are probably contributed both by the fetus and pregnant ewe.

In conclusion, these data suggest that active renin and renin substrate pass poorly into the amniotic fluid; and aldosterone passes well during development in the fetal sheep. It is unlikely that the renin-angiotensin-aldosterone system in amniotic fluid has a physiologic function. 


\section{REFERENCES AND NOTES}

1. Bangham, D. R.: The transmission of homologous serum proteins to the fetus and to the amniotic fluid in the rhesus monkey. J. Physiol. (Lond.), 53: 265 (1960).

2. Bayard, F., Ances, I. G., Tapper, A. J., Weldon, V. V., Kowarski, A., and Migeon, C. J.: Transplacental passage and fetal secretion of aldosterone. J. Clin. Invest., 49: 1389 (1970).

3. Behrman, R. E., and Kittinger, G. W.: Fetal and maternal responses to in utero angiotensin infusions in macaca mulatta. Proc. Soc. Exp. Biol. Med., 129: 305 (1968).

4. Craven, D.: The study of renin in human amniotic fluid and foetal membranes (unpublished $\mathrm{PhD}$ Thesis, University of Nottingham, 1978).

5. Eggena, P., Chu, C. L., Barrett, J., and Sambhi, M. P.: Purification and partial characterization of human angiotensinogen. Biochim. Biophys. Acta, 427: 208 (1976).

6. Ferris, T., Stein, J., and Kauffman, J.: Uterine blood flow and uterine renin secretion. J. Clin. Invest., 51: 2827 (1972).

7. Haber, E., Koerner, T., Page, L. B., Kliman, B., and Purnode, A.: Application of a radioimmunoassay for angiotensin $\mathrm{I}$ in normal human subjects. $J$. Clin. Endocrinol. Metab., 29: 1349 (1969).

8. Ito, T., Woo, J., Hening, R., and Horton, R.: A radioimmunoassay for aldosterone in human peripheral plasma including a comparison of alternate techniques. J. Clin. Endocrinol. Metab., 34: 106 (1972).

9. Lumbers, E. R.: Activation of renin in amniotic fluid by low pH. Enzymologia, 40: 329 (1971).

10. Pasquelini, S. R., Sumida, C., and Gelly, C.: Steroid hormone receptors in fetal guinea pig kidney. J. Steroid Biochem., 5: 977 (1974).

11. Siegel, S. R., and Fisher, D. A.: Ontogeny of the renin-angiotensin-aldosterone system in the fetal and newborn lamb. Pediatr. Res., 14: 99 (1980).

12. Siegel, S. R., Oakes, G., and Palmer, S.: The effects of angiotensin II on blood pressure, plasma renin activity and aldosterone in the fetal lamb. Dev. Pharm. Ther. (in press).

13. Siegel, S. R., Oakes, G., and Palmer, S.: Transplacental transfer of aldosterone and its effects on renal function in the fetal lamb. Pediatr. Res., 15: 163 (1981).
14. Skinner, S. L., Cran, E. J., Gibson, R., Taylor, R., Walters, W. A. W., and Catt, K. J.: Angiotensins $I$ and 2, active and inactive renin, renin substrate, renin activity, and angiotensinase in human liquor amnii and plasma. Am. J. Obstet. Gynecol., 121: 623 (1975).

15. Skinner, S. L., Dunn, J. R., Mazetti, J., Campbell, D. J., and Fidge, M. H.: Purification properties, and kinetics of sheep and human renin substrate. Aust. J. Exp. Biol. Med. Sci., 53: 77 (1975).

16. Skinner, S. L., Lumbers, E. R., and Symonds, E. M.: Renin concentration in human fetal and maternal tissues. Am. J. Obstet. Gynecol., 101: 529 (1968).

17. Smeby, R. R., and Bumpus, F. M.: Renin substrate. In: I. H. Page, J. W. McCubbin: Renal Hypertension. p. 20. (Year Book, Chicago, 1968).

18. Smith, F. G., Jr., Lupu, A. N., Barajas, L., Bauer, R., and Bashore, R. A.: The renin angiotensin system in the fetal lamb. Pediatr. Res., 8: 611 (1974).

19. Symonds, E. M., and Furler, I.: Plasma renin levels in the normal and anephric foetus at birth. Biol. Neonate, 23: 133 (1973).

20. Wintour, E. M., Barnes, A., Cahill, F., Hardy, K. W., Horacek, I., and Scoggins B. A.: Potassium: aldosterone relationships in pregnant ewes and chronically cannulated ovine fetuses. Pediatr. Res., 13: 265 (1979).

21. Wintour, E. M., Brown, E. H., Denton, D. A., Hardy, K. W., McDougall, W. G., Robinson, P. M., Rowe, E. W., and Whipp, G. T.: In vitro and in vivo adrenal cortical steroid production by fetal sheep: effect of angiotensin II, sodium deficiency, ACTH. In: C. Conti: Research on Steroids. Vol. III. pp. 475-485 (Elsevier/North Holland, Amsterdam, 1977).

22. Wintour, E. M., Coughlan, J. P., Hardy, K. W., Lingwood, B. E., Rayner, M., and Scoggins, D. A.: Placental transfer of aldosterone in the sheep. J. Endocrinol., 86: 305, 1980.

23. Requests for reprints should be addressed to: Sharon R. Siegel, M.D., UCLA Hospital and Clinics, Department of Pediatrics, 22-404 MDCC, Los Angeles, CA 90024 (USA).

24. This research was supported by Grant HD 13910-01 from the National Institutes of Child Health and Human Development, National Institutes of Health, Bethesda, MD.

25. Received for publication February 2, 1981

26. Accepted for publication April 6, 1981. 